\title{
The Limits of Anthropocene Narratives
}

\author{
Zoltán Boldizsár Simon \\ Bielefeld University
}

This is a draft version.

For the published article follow the link to the

European Journal of Social Theory (2018)

\begin{abstract}
The rapidly growing transdisciplinary enthusiasm about developing new kinds of Anthropocene stories is based on the shared assumption that the Anthropocene predicament is best made sense of by narrative means. Against this assumption, this article argues that the challenge we are facing today does not merely lie in telling either scientific, socio-political, or entangled Anthropocene narratives to come to terms with our current condition. Instead, the challenge lies in coming to grips with how the stories we can tell in the Anthropocene relate to the radical novelty of the Anthropocene condition about which no stories can be told. What we need to find are meaningful ways to reconcile an inherited commitment to narrativization and the collapse of storytelling as a vehicle of understanding the Anthropocene as our current predicament.
\end{abstract}

\section{Keywords}

Anthropocene, domesticating the new, historical narrative, humanity, politics, storytelling, unprecedented change 


\section{The Many Stories of the Anthropocene}

What kinds of stories does the Anthropocene challenge us to tell? Historians, social scientists, and literary scholars seem just as eager to answer this question today as earth scientists, geologists, and human geographers do. The answers themselves may be discipline-specific, and, among many other factors, largely vary along how one defines the Anthropocene and what one considers to be the beginning of the story. ${ }^{1}$ Stories that understand the Anthropocene as a geological epoch or stories that regard the notion as being integral to the relatively new knowledge formation known as Earth system science may take radically different twists and turns than stories that refer to a cultural condition or to a general human imprint on nature. Besides, a story based on stratigraphic data (Zalasiewicz et al., 2011), a story about biodiversity loss (Seddon et al., 2016), and a story that revolves around the mischiefs and wrongdoings of the central villain named capitalism (Moore, 2015), may not even have much in common.

I will come back to the question of differences soon. For now, the more important thing to note is that talking about the Anthropocene as a geological epoch-marker with a beginning makes sense only against the backdrop of an implied story. No wonder that the humanities and the social sciences - and lately especially the discipline of history - have found their way to join the discussion initiated by the natural sciences. Despite the large variety of approaches to Anthropocene narratives, a shared sense has already been developed that the most plausible stories should somehow feature multiple timescales - from industrialization processes to planetary histories - and achieve a transdisciplinary character by bringing most of the above concerns and elements together. Such an expectation has already been present in Paul Crutzen's brief essay in Nature, which kick-started the spectacular career of the term at the beginning of the new millennium. In suggesting the eighteenth century as the onset of the Anthropocene, Crutzen (2002: 23) referred to 'analyses of air trapped in polar ice' that 'showed the beginning of growing global concentrations of carbon dioxide and methane' in this period, and also noted that this data 'happens to coincide with James Watt's design of the steam engine in 1784'.

Noting a coincidence between possible Anthropocene stories told by the natural sciences on the one hand and the humanities and social sciences on the other does not, however, put the respective stories into any meaningful relation to each other. The same applies to the 'Great Acceleration' thesis, which sets the 
beginning of the Anthropocene in the early postwar years. The thesis works from an Earth system science point of view, which brings together various disciplines of the natural sciences in considering the Earth as a whole, an integrated system on its own. The term 'Great Acceleration' refers to a simultaneous postwar runaway of socio-economic trends (including urban population, water use, GDP, or transportation) and Earth system indicators (such as stratospheric ozone, ocean acidification, shrimp aquaculture, or terrestrial biosphere degradation). Although its advocates are aware of the fact that 'correlation in time does not prove causeand-effect', they think that 'there is a vast amount of evidence that the changes and in the structure and functioning of the Earth System [...] are primarily driven by human activities' (Steffen et al, 2015: 92).

But even if the cause-and-effect relationship between histories of the human world and histories of the Earth system could be established, from the viewpoint of the humanities and social sciences this would typically result in rather unsophisticated narratives. It would still be the standard Earth story, the latest episode of which features human beings as new geological agents. Needless to say, according to much of humanities and social sciences criticism, this actually is the paradigmatic Anthropocene story as told by the natural sciences. Critics point out that even though the natural sciences have done an invaluable service in calling attention to human-induced changes in the Earth system and their potential consequences, the social embeddedness of the supposedly universal humanity that features as the novel geological agent in Anthropocene narratives of the Earth system should receive just as much attention.

Going back to Crutzen's temporal coincidence between what stratigraphic data shows and Watt's steam engine, Andreas Malm and Alf Hornborg (2014: 92) tell a completely different story, in which 'capitalists in a small corner of a the Western world invested in steam, laying the foundation stone for fossil economy'. In offering a brief sketch of the history of this fossil economy, they emphasize the responsibility of 'advanced capitalist countries' in bringing about the current situation. Malm and Hornborg (2014: 64) note that 'in the early 21st century, the poorest $45 \%$ of the human population accounted for $7 \%$ of emissions, while the richest $7 \%$ produced $50 \%$ ' and go on to ask the rhetorical question: 'Are these basic facts reconcilable with a view of humankind as the new geological agent?'

Eventually, Malm and Hornborg (2014: 66) end up claiming that the standard natural scientific Anthropocene story represents 'an illogical and 
ultimately self-defeating foray of the natural sciences - responsible for the original discovery of climate change - into the domain of human affairs', and that 'in Anthropocene thinking, natural scientists extend their world views to society'. And they are not the only ones to think so. The recent book of historians Christophe Bonneuil and Jean-Baptiste Fressoz, The Shock of the Anthropocene (the 2016 translation of the French book originally published in 2013), rhymes off these sentiments, depicting the same scientific Anthropocene narrative as if it conveyed the hidden agenda of science aspiring world governance. Although Bonneuil and Fressoz start out by crediting the sciences of doing a great job at recognizing and establishing the situation to face, they accuse natural sciences with a depoliticization of very situation they describe. They think that there is one 'official' Anthropocene narrative out there that must be bitterly countered, and that a proper understanding of the Anthropocene must be based on historical Anthropocene narratives that tell how a differentiated human world arrived at the present situation.

There are nevertheless good arguments indicating that this kind of animosity, just as well as the idea that scientific Anthropocene stories wish to intrude and overtake the way we think about the human world, is unjustified and misplaced. First, if anything, such stories seem to be either of the completely opposite effect or of the implausibility to think about nature and the human world in terms of one dominating the other. What they are trying to convince us about is not that we should look at the human world 'scientifically', but that this human world - with all that comes with it - is now irreversibly acting into and transforming the order of nature, compelling us to redefine the way we think about the relationship between nature and the human world as intertwined.2 What is more, most scientific Anthropocene narratives entail a kind of anthropocentrism manifested in the acknowledgement of the unprecedented powers of human beings in transforming the Earth system. Even if they abandon the idea of human exceptionalism by collapsing a strict conceptual separation between nature and the human world, what they are often being criticized by the emerging discourses of anti-anthropocentric critical posthumanism and ecological humanities of human-nonhuman kinship (Braidotti, 2013; Haraway, 2016) is precisely their anthropocentrism.

Second, as Julia Adeney Thomas (2018: 177) notes, scientific Anthropocene stories and 'ESS [Earth system science] scientists are not in the business of blame'. 
Dipesh Chakrabarty (2017: 28) makes the same point when claiming that the notion of the Anthropocene as emerged in the natural sciences 'refers more to (mostly human-driven) changes to the Earth system as a whole and less about moral culpability of humans (or some humans) in causing them'. Finally, in his recent book, Defiant Earth: The Fate of Humans in the Anthropocene (2017), Clive Hamilton even provides an explanation for the confusion in arguing that the Anthropocene represents a paradigm shift inseparable from the new-born Earth System science. In Hamilton's view, it is within this new knowledge formation which may indeed be new in the sense of emerging in the broadly construed postwar period - that the Anthropocene has been conceived as a novel understanding of humanity's role in the equally novel conception of the Earth as an integral system. The problem with the understanding of the situation by much of humanities and social sciences scholarship is, accordingly, that they 'read the Anthropocene into the old disciplines with which they are comfortable' (Hamilton, 2017: 20).

I think that these latter remarks raise a valid point. Many interventions into what is conceived of as a monumental Anthropocene story of the natural sciences oftentimes result in nonetheless standard evocations of what, by now, appears as a rather conventional and predictable critical arsenal of humanities and social sciences scholarship. Motivated by the anxiety that scientific Anthropocene stories erase their categories of understanding out of the picture, humanities and social science engagements with the Anthropocene can easily be just as reductionist and one-sided as, in their view, natural scientific Anthropocene narratives are. While claiming to balance the overall picture, often they gesture toward the other extreme pole.

Such sense of mutual exclusivity derives from the assumption that telling one kind of Anthropocene story may render other kinds impossible to tell. In turn, the assumption that different kinds of Anthropocene narratives anaesthetize (at best) or inactivate (at worst) each other is based on the deeper conviction that these stories are about the same thing, and that the plausibility of one kind of narrative must come at the expense of the plausibility of other kinds. Contrary to this, it seems to me that scientific Anthropocene narratives on the one hand and sociopolitical ones on the other are typically about different things. They are simply based on conflicting imperatives. Whereas scientific Anthropocene narratives demand preemptive action in facing an existential risk, the narratives of the 
humanities and social sciences typically demand social justice and entail proactive social engagement (Simon 2017). The latter demand is hardly intelligible in case of a story which - as indicated by the above arguments of Thomas, Chakrabarty, and Hamilton - features the Earth system as its central character and as a subject of change. The demand for social justice underlying socio-political Anthropocene stories concerns a subject other than the Earth system. It wishes to introduce changes in the condition of a socio-politically deprived subject of the human world.

More on this later. At this point, the question that has to be asked goes as follows: where does all this leave us? Does this mean the expectation of transdisciplinarity concerning the most plausible Anthropocene stories is out of the question? The countless calls (Castree et al., 2014; Thomas, 2014; Clark and Gunaratam, 2017; Toivanen et al., 2017; Robin, 2018) for joined investigations to find meaningful ways to relate stories of the Earth system and narratives of a socio-politically divided human world most certainly suggests otherwise. Can it be then that all calls, pleas, and efforts of making sense by crafting entangled Anthropocene narratives, testify a possibility and a necessity, but, at the same time, are nevertheless misplaced in one way or another? Well, this may be closer to the point I would like to make, although it still sounds a bit too harsh. I firmly believe that we can tell stories in the Anthropocene and such stories may be novel kinds. What I think we cannot tell are stories about the Anthropocene. The former means that we can tell entangled and truly transdisciplinary stories of how the current condition came about and what factors contributed to arriving at this point. Yet such stories do not permit a better understanding of the condition, that is, the Anthropocene predicament itself.

In the coming pages, I argue that the challenge we face today does not merely lie in developing either scientific, socio-political, or entangled Anthropocene stories to come to terms with our current condition. Instead, the challenge lies in coming to grips with how the stories we can (but not necessarily should) tell in the Anthropocene relate to the radical novelty of the Anthropocene condition about which no stories can be told. What we need is to find meaningful ways to reconcile what apparently is a retained commitment to narrative understanding with the collapse of storytelling as a vehicle of comprehending the Anthropocene as our current predicament. 
I try to render this claim plausible in four consecutive steps. I begin with a brief overview of narrative understanding as associated with historical understanding. Then, in the second step, I indicate both the retained necessity and the shortcomings of storytelling by engaging with Dipesh Chakrabarty's most inspiring efforts to bring together stories of nature and the human world. As a third step, I elaborate on the other side of the equation: the Anthropocene as radical novelty, as rupture, as shock, and as unprecedented change. Finally, in the concluding step I contend that although the narrative domestication of such radical novelty may be necessary, it is not necessarily the kind of understanding and the kind of politics required for coming to terms with the Anthropocene predicament.

\section{Narrative Understanding and the Anthropocene}

Telling Anthropocene stories is, so to say, only half of the story. To come to a proper understanding of our current condition, we need to explore the extent to which the Anthropocene renders storytelling impossible. Such a recognition of the limits of understanding and sense-making by means of storytelling could yield to a twofold benefit. On the one hand, it would open the way for developing new ways of understanding specifically tailored to the novelty of the predicament itself. On the other, probing the boundaries of storytelling would be the most instrumental precisely in finding out what kinds of Anthropocene narratives are still possible to tell.

All this may sound odd, I reckon. Do not we have history as the paradigmatic narrative discipline in the scholarly world, endowed with the potential to craft elaborated Anthropocene stories to the satisfaction of everyone? Philosophers of history and theoretically minded historians have answered the question of narrative affirmatively in the last more than half-century. In one way or another, the major theoretical approaches to history after the Second World War converged in their understanding of history as a narrative enterprise. From the 1950s onwards, analytic philosophers have begun to argue that historical descriptions of events presuppose a narrative organization (Danto, 1985 [1965]); that narrative is self-explanatory (Gallie, 1964); or that it is a cognitive instrument (Mink, 1987). Yet what most historians and theorists associate (even today) with a broadly construed narrativist position is rather Hayden White's more literary theory- 
inspired approach to historical narrative as a subgenre of literary writing and a culturally sanctioned mode of meaning-making. It was White's seminal Metahistory (1973), and perhaps even more his collections of essays (White, 1978; 1987), which provoked oftentimes heated responses within the discipline of history in the 1990s. ${ }^{3}$ At the same time, Frank Ankersmit $(1983$; 1994) developed his own influential version of narrativism; phenomenologists extended the narrativist view to the human experience of time (Ricœur, 1984-1988; Carr, 1986); and narrative has become a cross-disciplinary fascination as a general way of making sense of the world and ourselves (Meretoja, 2014).

This tiny sample of a far larger body of work is necessarily selective. As an assemblage of positions on the question of the role of narrative in history, it is nevertheless indicative enough concerning the dominance of the theoretical understanding of the historical enterprise as a narrative one in the second half of the last century (while the theoretical field moves towards other kinds of concerns since then). ${ }^{4}$ But narrative as a vehicle of historical understanding has not been merely a fancy of a handful of theorists and theoretically inclined historians. As the latest version of the American Historical Association's 'Statement on Standards of Professional Conduct' (2018) clearly indicates, it is simply part of the professional code of historical studies. According to the statement, "we all interpret and narrate the past, which is to say that we all participate in making history. It is among our most fundamental tools for understanding ourselves and the world around us.' Besides, the 'shared values for conducting and assessing research, developing and evaluating interpretations, communicating new knowledge, navigating ethical dilemmas, and, not least, telling stories about the past, define the professional practice of history' ${ }^{5}$

Given all this, no wonder that Bonneuil and Fressoz approach the Anthropocene by trying to fulfil the role of storytellers. First, they want to deconstruct what they see as the 'Geocratic Grand Narrative of the Anthropocene' told by the natural sciences (Bonneuil and Fressoz, 2016: 45-96). Then, instead of such a monolithic narrative, Bonneuil and Fressoz (2016: 289) suggest that making sense of 'what happened to us' means 'producing multiple, debatable and polemical narratives rather than a single hegemonic narrative that is supposedly apolitical'. Although the claim concerning the existence of one 'single hegemonic' natural scientific Anthropocene story (and that it is apolitical) is debatable, ${ }^{6}$ my intention here is only to call attention to their narrative approach. This is what 
they need to be credited for as this is what they truly excel at. They propose no less than seven imaginatively entitled alternative narratives, such as the Thermocene (which they offer as a political history of $\mathrm{CO}_{2}$ ) or the Phagocene (a story of increasing commodification).

The felt need of crafting Anthropocene narratives is nevertheless not confined to historical studies. It crosses every possible disciplinary boundaries, and, according to Bruno Latour, there are good reasons for that. With the Earth becoming 'a full-fledged actor', he does not think with Bonneuil and Fressoz that what we need are multiple stories. Instead, Latour (2014: 15) makes the case for the necessity of a convergence of possible stories, bringing together human and non-human actors in what he refers to as 'our common geostory', which should somehow feature all agents from plate tectonics and microbes to novelists and politicians. What nevertheless brings this to a shared platform with Bonneuil and Fressoz is the way Latour (2014: 5) thinks that 'the problem for all of us in philosophy, science, or literature becomes: how do we tell such a story?'

\section{Larger Scale, Same Kind of Story}

Indeed, how do we tell such a story? Back to historical studies, Dipesh Chakrabarty tries to answer the question in the most stimulating and thoughtful way. Since pioneering into the theme of what the Anthropocene demands from historical thinking in the article 'The Climate of History' (2009), Chakrabarty is engaged in mapping the possibility of Anthropocene narratives on a level that constitutes the shared fundament of both a Latourian common geostory and the multiple polemical narratives of Bonneuil and Fressoz: to develop a conceptual apparatus that could enable us to conceive of human history and Earth history as entangled.

Accordingly, there hardly is a more elaborate endeavor to indicate the qualities, features, potential merits and shortcoming of Anthropocene narratives than Chakrabarty's decade-long engagement. It boils down to a series of conceptual distinctions regarding the scale, the central characters, the underlying temporalities, and the implied worldviews of entangled Anthropocene stories. The distinctions are heavily interrelated and Chakrabarty tends to revisit and constantly elaborate on them. The entry point of a brief introduction to such a complex endeavor might just as well be the question of scale, being the most easily 
distinguishable. Chakrabarty (2014: 1) claims that our current predicament is marked by the collision of three histories, 'normally' treated 'as processes separate from one another for all practical purposes: the history of the earth system, the history of life including that of human evolution on the planet, and the more recent history of industrial civilization (for many, capitalism)'.

Putting these histories into a meaningful relationship needs central characters, but these protagonists do not necessarily overlap scales in the sense that one central character could be attributed to each. They rather cut across the scales. In the above tripartite division, the history of industrial civilization or capitalism and the history of life jointly represent the world of human or humanrelated affairs, and the history of Earth system is the story of nature. In the former two scales, the main character is an internally divided humanity. Whereas the story of capitalism plays out the extent to which intra-human inequalities are effective, in the story of humanity (to which Chakrabarty often refers to as world history) the central character is not divided into rich and poor. There is, however, 'the history of population', which 'belongs to two histories at once': on the one hand, there is 'the very short-term history of the industrial way of life', and, on the other, there is the 'longer-term evolutionary or deep history of our species, the history through which we have evolved to be the dominant species of the planet', and 'the poor participate in that shared history of human evolution just as much as the rich do' (Chakrabarty, 2014: 14).

Seen together, the story of capitalism in which the rich are the most effective is intertwined with the story of human evolution featuring the protagonist called 'species', while, in the words of Chakrabarty (2014:15), 'population is clearly a category that joins the two histories'. But what about the history of the Earth system? Its protagonist, Chakrabarty (2018: 25) claims, is 'the Earth system itself, not humans', and the Earth system story itself belongs to 'the time of geology, vast and incomprehensible in terms of the concerns of human history'. At the same time, however, once humans appear in the story, 'geological time gets written over by the human time of world history, and humans emerge as the subject of the drama of the Anthropocene, not just in the writings of scholars in the human sciences but often in those of earth scientists themselves' (Chakrabarty, 2018: 25).

The latter move constitutes 'the moral side of the Anthropocene debate', involving a necessary act of displacement, that is, the translation of 'ideas that have deeply to do with Earth history, geology, and geological time into the 
language of world history' (Chakrabarty, 2018: 9). But this translation works in the opposite direction too. For the human that enters geological time is not simply the human of the historical time of world history. In his Tanner Lectures in Human Values, Chakrabarty (2015: 173-174) distinguishes between two understandings of the human as homo and anthropos. Whereas the former denotes 'humanity as a divided political subject', the anthropos refers to the 'collective and unintended forms of existence of the human, as a geological force, as a species, as part of the history of life on this planet'. Chakrabarty (2015: 154-165, 167-173) even widens this distinction into homocentric and zoecentric views of the world, which respectively account for histories revolving around humans understood in sociopolitical terms and histories in which humans are conceived of within a larger scheme of life (zoe). Eventually, it is the anthropos of a zoecentric worldview which, according to Chakrabarty (2015: 174), 'decenters the human by subordinating human history to geological and evolutionary histories of the planet'. ${ }^{7}$

The above distinctions do not necessarily overlap. Some of them even seem to conflict. It is not clear, for instance, whether a distinction between worldviews which results in the absorption of smaller scale histories by deeper histories amounts to a genuine entanglement of those histories or rather requires the ability to constantly shift between the worldviews and their respectively implied histories. Chakrabarty's intention to create the conceptual possibility of bringing together stories of different scales, main characters, temporalities, and worldviews in a deep processual Anthropocene narrative is nevertheless clear. Needless to say, this amounts to a major and, to my mind, unparalleled achievement. But it is not without shortcomings.

Already in his initial engagement with the Anthropocene, Chakrabarty (2009: 197, 220) phrased the main challenge as the collapse of historical understanding in facing an extreme Anthropocene prospect of a 'world without us' that defies the 'continuity of human experience'. Since then, his work has been focused on the extent to which the monumental scale of Anthropocene narratives escapes the confines of human experience. At the same time, he remained relatively silent about the extent to which the continuity of such experience is threatened. Differently put, the attention Chakrabarty is paying to question of how to tell stories about that which cannot be experienced by human beings as human beings (a species history of the anthropos, a zoecentric view, geological time) is accompanied by an inattention toward that which defies the continuity 
underlying all stories, regardless of whether their scale is human or larger-thanhuman.

The storytelling of continuous unfolding retains the idea of modern Western historicity that change over time in human affairs is best conceived of as processual and developmental. Historical understanding and modern historical time underlies Anthropocene narratives of all scales. And there is not much surprise in this. For there is at least one crucial aspect in which there has been no divide between nature and the human world that only the Anthropocene could have collapsed lately. It can very well be that, as Bonneuil and Fressoz (2016: 37) point out, history as we know it in its professionalized and institutionalized form has concerned human affairs and it could scarcely interact with the history of nature, the timescales being different'. But the question of scale is only one indicator, far from being the primary. On a deeper level, Western modernity has connected the human and the natural world when it has begun to conceive of both as 'historical' by virtue of seeing them in terms of a developmental process. According to Maurice Mandelbaum's study of nineteenth-century thought (1971: 77-111), evolutionary thinking about the natural world emerged as the equivalent of the historicist developmental view of the human world, both accounting for their investigated natural and social phenomena 'historically'. Similarly, as Hannah Arendt (1961: 61) remarks, 'the connection between concepts of nature and history' was the idea of 'process', and the 'key words of modern historiography - "development" and "progress" - were, in the nineteenth century, also the key words of the then new branches of natural science, particularly biology and geology, one dealing with animal life and the other even with nonorganic matter in terms of historical processes'.

Entangling natural scientific Anthropocene narratives and human histories goes relatively easily today precisely because modernity has already storied the natural and the human world along the same kind of processual changes. Questions of the diverging scales, the different paces, and multiple protagonists of change are the main difficulties to overcome for entangled Anthropocene stories. But these are, I think, only difficulties and thus are not constitutive of the more critical challenge. The most puzzling question today is not that of how to handle various scales, speeds, and actors of stories, all of which are constructed along a shared type of change, but that of how far we can go on in telling such 
stories of processes when the Anthropocene confronts us with a type of perceived change that is anything but processual.

\section{Unprecedented Change, Rupture, Shock, Event}

The extent to which the Anthropocene resists processual narratives on all scales is the extent to which it defies, as Chakrabarty says, the continuity of human experience. Against the backdrop of such continuity, at its most extreme, the Anthropocene threatens to put an end to the human subject of entangled stories. Although potential human extinction scenarios entailed by radical Anthropocene scenarios - together with technological dystopias of singularity reached by designing greater-than-human intelligence and with visions of a nuclear holocaust - are often denounced as instances unjustified catastrophism, they represent a novel societal expectation of the future in which humanity authors its own disaster. As I argued elsewhere (Simon, 2015; 2018), these prospects of anthropogenic human extinction are constitutive of an emerging sense of historicity. Unlike the historical understanding of the modern period which conceives of change over time both in nature and society in terms of developmental processes, postwar Western societies configure change over time in these prospects as unprecedented change. Instead of unfolding from past states affairs, such a change brings about a disconnection between past states of affairs and a completely novel predicament by a suddenly erupting game-changer event. If the Anthropocene predicament includes such prospect of unprecedentedness as disconnection from the past without being restricted to it, then the question is how to reconcile this with our storytelling activity in which we manifest the continuity of our experience.

The notion of unprecedented change is not the only conceptualization of the radical novelty of the Anthropocene predicament. The Anthropocene can be conceived of as resisting storytelling by means other than its future prospect and with respect to domains other than human affairs. Clive Hamilton's conceptualization of the Anthropocene as rupture concerns the natural world and Earth history (Hamilton, 2017: 1-35). As mentioned earlier, Hamilton argues that the birth of Earth system science is a paradigm shift, and the Anthropocene is a notion that cannot be understood outside the paradigm within which it has been conceived. Although Hamilton only passingly references Thomas Kuhn's book 
The Structure of Scientific Revolutions as the source of his ideas on a recent paradigm shift, it seems important to point out that in the Kuhnian sense the new paradigm is incommensurable with old one it replaces.

What does such incommensurability mean? The term literally refers to the lack of common measure, but the metaphorical description of Kuhn (1996 [1962]: 150) suggests somewhat more when claiming that 'proponents of competing paradigms practice their trades in different worlds'. Read together with the fact that Kuhn advocated the idea of paradigm shifts as seldom revolutionary events against the reigning understanding of the history of science as a cumulative process, the above characterization of a new paradigm's relation to the old seems to entail a sense of historicity and a new understanding of change over time akin to the notion of unprecedented change. Conceiving of the Anthropocene as rupture brought about by a new paradigm means nothing other than seeing it as a predicament that does not arise out of a cumulative process. The effect is the same as in the case of unprecedented change: the new predicament, not being perceived as a product of a development, withstands the processual rendering of Anthropocene stories.

Yet another indication of the perception of the Anthropocene as radical novelty is to talk about its shock, as in the title of Bonneuil and Fressoz's book. The Shock of the Anthropocene can nevertheless be misleading in that the concept Bonneuil and Fressoz work with is that of the 'event' of the Anthropocene, which actually features in the original French title of the book (L'événement Anthropocène). But regardless of whether one talks about a shock or an event of the Anthropocene, it entails a distinct disruptive character attributed to an emerging overall condition. Accordingly, Bonneuil and Fressoz (2016:19) do not hesitate to describe the situation in a dramatic tone, claiming that 'the Anthropocene is an event, a point of bifurcation in the history of Earth, life and humans. It overturns our representations of the world'. Although these words claim radical novelty with respect both to our conceptions of nature and human affairs, and although 'bifurcation' and the 'overturning of our representations of the world' imply a break between pre- and post-Anthropocene modes of thought, Bonneuil and Fressoz devote two-thirds of their book to their seven Anthropocene narratives, continuing to represent the world by the familiar means of processual historical narratives. The same applies to Hamilton. His arguments for the Anthropocene as rupture are undermined by a desire for 'a new narrative of narratives' (Hamilton 
2017: 77), that is, an updated version of the old story of humanity (which of course Bonneuil and Fressoz would disapprove of):

And so we gaze into a future of the progressive elimination of difference in a globalized world, coupled with the dawning of an Anthropocene that, over the next decades, must increasingly rule over everyday life and consciousness wherever one resides, opening up space for a world narrative and perhaps a philosophy of global history. Above all of the diversity stand one global economy, one global culture, one total Earth. The Anthropocene arrives as the grand narrative to progressively order and explain experience, the universal truth all humanity is obliged to live under, a narrative that, like it or not, subsumes all others and against which they will be judged. As it gathers pace the tyranny of the Earth System will overrule the plurality of local stories and cultures. If the Anthropocene performs this unexpected and unwelcome unification of humankind then it invites us to formulate a story of humankind, a narrative explanation of the progress of human history as a whole [...]. (Hamilton, 2017: 84-85)

There can hardly be a clearer indication of the intricacies and perplexities of the Anthropocene predicament than the fact that even those who claim the radical novelty of the Anthropocene cannot but have a recourse to inherited schemes in their efforts to make sense of it, thereby trivializing and domesticating their own insights.

To avoid misunderstanding, my intention by pointing this out is merely to raise attention to what I think is the greatest challenge: making sense of that which appears to defy our familiar ways of sense-making. I not wish to pretend that I have a way out of this conceptual Catch-22, but, in the first place, we need to understand that we are in it: on the one hand, we tend to think of the Anthropocene as the radical event, rupture, and unprecedented change that rewrites disciplinary codes as we know them and demands new arrangements of knowledge we are yet to establish; on the other, we still think about our radically new predicament in terms of our more familiar arrangements of knowledge and keep on telling processual narratives about the Anthropocene (just as we did about practically anything in the modern period).

This, I believe, is the fundamental paradox of our current understanding of the Anthropocene. Regardless of whether one wants to tell a single grand narrative on the planetary scale as Hamilton does, multiple and polemical stories as Bonneuil and Fressoz advocate, or an entangled story of timescales, central characters and worldviews as Chakrabarty suggests, the sheer act of telling Anthropocene narratives is in conflict with the necessity of recognizing the novelty of the situation. Accordingly, what we need to come to terms with is the 
question of whether such potentially contradictory imperatives are constitutive of the very same predicament. In place of conclusion, a quick look at the politics of storytelling as the domestication of novelty may be the first step towards developing an answer to this question.

\section{A Politics for the Anthropocene}

The single most important contention of narrativism for recent efforts to understand the Anthropocene predicament is that the stories we tell domesticate that which they are about. Hayden White (1978: 256), in an essay on Foucault, calls the operation of rendering the strange familiar 'the essentially domesticating effect of all historical writing'. Besides, according to another essay of White (1987: 5882), this domesticating effect constitutes the 'politics of historical interpretation'. The Anthropocene predicament is of course completely alien to White's work. I do not want to suggest that White's views within either an aesthetic context or in the context of Foucault's attack on the 'historical' search for origins can unproblematically transferred into our context. But even if the Anthropocene is not merely something 'strange' that stories render familiar, it is certainly something unfamiliar that narratives familiarize. It is perceived radical novelty domesticated by storytelling.

The domesticating function of narrative attains a new and critical political dimension in the Anthropocene situation in which societal action is called for preventing future catastrophe. The more such perceived radical novelty is domesticated, the less radical and the less novel it appears, and thus the less it calls for mitigation. Domestication smooths novelty into larger processes we are already familiar with, so that it no longer appears as shock, rupture, and unprecedented. On the other hand, it is equally true that societal mobilization by pointing at threats to humanity - unified precisely by the threat itself - has another political dimension that is prone to treacherous misuse. Critics who warn for such misuse of speaking on behalf of an undifferentiated humankind (Malm and Hornborg, 2014; Bonneuil and Fressoz, 2016; Cohen and Colebrook, 2017) are of course right that this may have a depoliticizing effect. But as such depoliticization is of course a political act, we may just as well it the politics of depoliticization.

I think that both political dimensions - the politics of narrative domestication and the politics of depoliticization - are equally important. The 
main difference is, however, that whereas the former we are yet to explore, latter we have studied extensively and understand very well. Fears of depoliticization concern politics and the domain of the political as we know it and as we knew it throughout Western modernity. The anxiety grows out of the prospect that new and unfamiliar concepts, notions and ideas of an emerging scientific vocabulary re-introduce wrongdoings and injustices we know from the past by bracketing the political. Oddly enough, such anxiety about depoliticization is the primary source of the politics of narrative domestication, as it typically entails a habitual recourse to already established and standardized categories of both politics and humanities and social scientific scholarship. Projecting older categories over whatever novelty we conceive of is, however, the cornerstone of domestication inasmuch as it enables narrating the new in terms of the old. This operation, I believe, may easily prove to be an obstacle to affirming the necessity of a novel kind of politics of the Anthropocene for which categories are yet to be developed.

In light of the familiar categories of the humanities and social sciences it may seem that the humanity under threat is a notion that has already been deconstructed in the last decades. But it must equally be clear that this humanity under threat has not much to do with humanity as the universal subject expected to come to the happy fulfillment of its inherent capacities over the course of a developmental historical process - the notion of humanity targeted by humanities and social scientific criticism in the last decades. True enough, humanity under threat is a universal category, but it represents a new kind of universalism (a zoecentric one, according to Chakrabarty) that we fail even to attempt to understand if we simply condemn and deprecate the occurrence of familiar words - humankind or humanity - without making efforts to track the shifting meanings these words have achieved in a presently emerging and largely unfamiliar scientific and transdisciplinary discourse.

What this means is that, on the one hand, I wholeheartedly agree with Chakrabarty (2018: 29) that the task today with respect to the political is to 'reconfigure' it. And there is, in fact, no shortage of proposals and discussions concerning the potential kinds of politics to pursue (Biermann, 2014; Clark, 2014; Dalby, 2014; Purdy, 2015; Delanty and Mota, 2017). On the other hand, however, I am more skeptical about whether Chakrabarty's argument for the necessity of developing Anthropocene stories that meaningfully entangle world histories and Earth histories, historical time and geological time, homocentric and zoecentric 
worldviews, can succeed in such reconfiguration. True enough, these stories reconfigure the scale of political thinking and the role of the human with respect both to interspecies and intraspecies justice. But the extent to which they necessarily remain stories assigns them a political function that has been tailored to pre-Anthropocene concerns.

A politics for the Anthropocene, I believe, rather begins with the realization that storytelling domesticates the Anthropocene predicament. All this does not mean that Chakrabarty and Anthropocene storytellers are completely wrong about the necessity of Anthropocene narratives. Narrative domestication as a vehicle of understanding may remain indispensable for many reasons. Nor does this mean that critics of the notion of the Anthropocene, pointing at the undifferentiated mentions of the word humanity, are completely wrong. The most striking feature of recent Anthropocene discussions is precisely that most of the participants seem to be right in one way or another, despite the fact that their ways of understanding oftentimes conflict and contradict each other. This precisely is the case with the telling Anthropocene stories on the one hand and recognizing the shock and the unprecedented change of the Anthropocene on the other. We need to learn how to navigate carefully among potentially conflicting but equally compelling imperatives by exploring the extent to which each and every one of them may function as both vehicles and obstacles of understanding the Anthropocene predicament.

\section{Author biography}

Zoltán Boldizsár Simon is a research fellow and a board member of the Centre for Theories in Historical Research at Bielefeld University. He has written extensively both on historical theory and on the challenges posed by current ecological and technological prospects for journals ranging from The Anthropocene Review to History and Theory. His book History in Times of Unprecedented Change: A Theory for the $21^{\text {st }}$ Century is forthcoming with Bloomsbury in 2019.

\section{Notes}

1. Alternative proposals to date the Anthropocene vary from the domestication of animals to the postwar period. As a brief sample, see Smith and Zeder (2013), Lewis and Maslin (2015), and Steffen et al. (2015). 
2. It must be clear that the renegotiation of the nature-human divide does not mean a complete erasure of the distinction. It rather means an existential bond between the two which still remain, in many contexts, distinguishable. Nevertheless, Malm (2018) has recently argued for the necessity of retaining the distinction in order to be able to act. See also Hornborg (2017) arguing against a tendency in recent (post)humanities scholarship to abolish analytical distinctions.

3. Many eminent historians engaged critically with White's position in the 1990s (Himmelfarb, 1992; Marwick, 1995; Ginzburg, 2012: 165-179). For an overview of White's reception see Vann (1998).

4. For retrospective assessments of narrativism in history see Partner (2009) and Rigney (2013).

5. The statement is available at https://www.historians.org/jobs-and-professionaldevelopment/statements-standards-and-guidelines-of-the-discipline/statementon-standards-of-professional-conduct

6. Bonneuil and Fressoz are of course not alone in thinking that there is one grand scientific Anthropocene story. Arguments for the necessity of humanities' and social sciences' viewpoints in a wider debate typically deploy the trope. See, for instance, Lövbrand et al. (2015); for a counter-argument see Thomas (2018).

7. The distinction between homocentric and zoecentric worldviews corresponds to the more recent distinction of Chakrabarty (2018: 22-29) between human-centered and planet-centered ways of thinking.

\section{References}

Ankersmit FR (1983) Narrative Logic: A Semantic Analysis of the Historian's Language. The Hague: Martinus Nijhoff.

Ankersmit FR (1994) History and Tropology: The Rise and Fall of Metaphor. Berkeley: University of California Press.

Arendt H (1961) Between Past and Future: Six Exercises in Political Thought. New York: The Viking Press.

Biermann F (2014) The Anthropocene: A Governance Perspective. The Anthropocene Review 1(1): 57-61.

Braidotti R (2013) The Posthuman. Cambridge: Polity. 
Bonneuil C and Fressoz J-B (2016) The Shock of the Anthropocene: The Earth, History and Us. London: Verso.

Carr D (1986) Time, Narrative and History. Bloomington: Indiana University Press.

Castree N, at al. (2014) Changing the Intellectual Climate. Nature Climate Change 4: 763-768.

Chakrabarty D (2009) The Climate of History: Four Theses. Critical Inquiry 35(2): 197-222.

Chakrabarty D (2014) Climate and Capital: On Conjoined Histories. Critical Inquiry 41(1): 1-23.

Chakrabarty D (2015) The Human Condition in the Anthropocene. The Tanner Lectures in Human Values, Yale University, February 18-19. Available at: https:/ / tannerlectures.utah.edu/Chakrabarty $\% 20$

manuscript.pdf

Chakrabarty D (2017) The Politics of Climate Change Is More Than the Politics of Capitalism. Theory, Culture E Society 34(2-3): 25-37.

Chakrabarty D (2018) Anthropocene Time. History and Theory 57(1): 5-32.

Clark, N (2014) Geo-politics and the Disaster of the Anthropocene. The Sociological Review 62(S1): 19-37.

Clark N and Gunaratam Y (2017) Earthing the Anthropos? From 'Socializing the Anthropocene' to Geologizing the Social. European Journal of Social Theory 20(1): 146-163.

Cohen T and Colebrook C (2017) Vortices: On 'Critical Climate Change' as a Project. South Atlantic Quarterly 116(1): 129-143. 
Crutzen, PJ (2002) Geology of Mankind. Nature 415: 23.

Dalby S (2014) Rethinking Geopolitics: Climate Security in the Anthropocene. Global Policy 5(1): 1-9.

Danto AC (1985 [1965]) Narration and Knowledge: Including the Integral Text of Analytical Philosophy of History. New York: Columbia University Press.

Delanty G and Mota A (2017) Governing the Anthropocene: Agency, Governance, Knowledge. European Journal of Social Theory 20(1): 9-38.

Gallie, WB (1964) Philosophy and the Historical Understanding. London: Chatto \& Windus.

Ginzburg C (2012) Just One Witness: The Extermination of Jews and the Principle of Reality. In: Ginzburg, Carlo, Threads and Traces: True, False, Fictive. Berkeley: University of California Press, 2012, 164-179.

Hamilton C (2017) Defiant Earth: The Fate of Humans in the Anthropocene. Cambridge: Polity.

Haraway DJ (2016) Staying with the Trouble: Making Kin in the Chthulucene. Durham and London: Duke University Press.

Himmelfarb G (1992), Telling It As You Like It: Post-Modernist History and the Flight From Fact. Times Literary Supplement, 16 October: 12-15.

Hornborg A (2017) Artifacts Have Consequences, Not Agency: Toward a Critical Theory of Global Environmental History. European Journal of Social Theory 20(1): 95-110.

Kuhn T (1996 [1962]) The Structure of Scientific Revolutions. Chicago: University of Chicago Press. 
Latour B (2014) Agency at the Time of the Anthropocene. New Literary History 45(1): 1-18.

Lewis SL and Maslin MA (2015) Defining the Anthropocene. Nature 519: 171- 180.

Lövbrand E, et al. (2015) Who Speaks for the Future of Earth? How Critical Social Science Can Extend the Conversation on the Anthropocene. Global Environmental Change 32: 211-218.

Malm A (2018) The Progress of This Storm: Nature and Society in a Warming World. London: Verso.

Malm A and Hornborg A (2014) A Geology of Mankind? A Critique of the Anthropocene Narrative. The Anthropocene Review 1:1 (2014): 62-69.

Mandelbaum M (1971) History, Man, E Reason: A Study in Nineteenth-Century Thought. Baltimore: Johns Hopkins Press.

Marwick A (1995) Two Approaches to Historical Study: The Metaphysical (Including 'Postmodernism') and the Historical. Journal of Contemporary History 30(1): 5-35.

Meretoja H (2014) Narrative and Human Existence: Ontology, Epistemology, and Ethics. New Literary History 45(1): 89-109.

Mink LO (1987) Narrative Form as a Cognitive Instrument. In: Mink, Louis O., Historical Understanding. Ithaca and London: Cornell University Press.

Moore JW (2015) Capitalism in the Web of Life: Ecology and the Accumulation of Capital. London: Verso.

Partner N (2009) Narrative Persistence: The Post-Postmodern Life of Narrative Theory. In: Ankersmit, Frank, Domanska, Ewa and Kellner, Hans (eds.) ReFiguring Hayden White. Stanford: Stanford University Press, 81-104. 
Purdy J (2015) After Nature: A Politics for the Anthropocene. Cambridge, MA: Harvard University Press.

Ricœur P (1984-1988) Time and Narrative, 3 vols. Chicago: University of Chicago Press.

Rigney A (2013) History as Text: Narrative Theory and History. In Partner, Nancy and Foot, Sarah (eds) The SAGE Handbook of Historical Theory. Los Angeles: SAGE, 183-201.

Robin L (2018) Environmental Humanities and Climate Change: Understanding Humans Geologically and Other Life Forms Ethically. WIREs Climate Change 9:e499.

Seddon N, et al. (2016) Biodiversity in the Anthropocene: Prospects and Policy. Philosophical Transactions of the Royal Society B: Biological Sciences 283: 20162094.

Simon, ZB (2015) History Manifested: Making Sense of Unprecedented Change. European Review of History 22(5): 818-834.

Simon, ZB (2017) Why the Anthropocene Has No History: Facing the Unprecedented. The Anthropocene Review 4(3): 239-245.

Simon, ZB (2018) (The Impossibility of) Acting upon a Story That We Can Believe. Rethinking History 22(1): 105-125.

Smith BD and Zeder MA (2013) The Onset of the Anthropocene. Anthropocene 4: 8-13.

Steffen W, et al. (2015) The Trajectory of the Anthropocene: The Great Acceleration. The Anthropocene Review 2(1): 81-98.

Thomas, JA (2014) History and Biology in the Anthropocene: Problems of Scale, Problems of Value. American Historical Review 119(5): 1587-1607. 
Thomas, JA (2018) Confronting Climate Change: The Uneasy Alliance of Scientists and Nonscientists in a Neoliberal World. Environmental History 23(1): 172-182.

Toivanen, T. et al. (2017) The Many Anthropocenes: A Transdisciplinary Challenge for the Anthropocene Research. The Anthropocene Review 4(3): 183-198.

Vann, RT (1998) The Reception of Hayden White. History and Theory 37(2): 143-16.

White H (1973) Metahistory: The Historical Imagination in Nineteenth-Century Europe. Baltimore: Johns Hopkins University Press.

White H (1978) Tropics of Discourse: Essays in Cultural Criticism. Baltimore: Johns Hopkins University Press.

White H (1987) The Content of the Form: Narrative Discourse and Historical Representation. Baltimore: Johns Hopkins University Press.

Zalasiewicz J, et al. (2011) Stratigraphy of the Anthropocene. Philosophical Transactions of the Royal Society A: Mathematical, Physical and Engineering Sciences 369: 1036-1055. 